\title{
APPLICATION OF SUPPLY CHAIN MANAGEMENT IN CONSTRUCTION INDUSTRY
}

\author{
Phong Thanh Nguyen 1,3, Vi Nguyen Nguyen², Luan Hong Pham², Thu Anh Nguyen², Quyen Le \\ Hoang Thuy To Nguyen ${ }^{3}$, Vy Dang Bich Huynh ${ }^{3}$
}
1 Construction Engineering and Management (CEM) division, Department of Civil Engineering, Faculty of Engineering, Chulalongkorn University (CU), 254 Phayathai Road, Pathumwan, Bangkok Thailand, e-mail: ntphong1711@gmail.com
2 Department of Construction Engineering and Management, Faculty of Civil Engineeirng, Ho Chi Minh City University of Technology (HCMUT), 268 Ly Thuong Kiet Road, Ho Chi Minh City, Vietnam, e-mail: nguyenvi0808@gmail.com, nathu@hcmut.edu.vn, ph.luan@hcmut.edu.vn
3 Department of Project Management, Ho Chi Minh City Open University (HCMCOU), 97 Vo Van Tan Road, Ho Chi Minh City, Vietnam, e-mail: phong.nt@ou.edu.vn, quyen.nlhtt@ou.edu.vn, vy.hdb@ou.edu.vn

Received: 2017.05.28

Accepted: 2018.04.01

Published: 2018.06.01

\begin{abstract}
The application of the supply chain management (SCM) in industry has achieved much success, especially in the manufacturing sector. In the current market, the Vietnamese construction companies must compete not only with domestic companies but also with foreign ones, the application of SCM is essential to improve efficiency and increase their competitive advantage. In this paper, a survey was carried out to identify factors that cause limitation in applying SCM to the Vietnamese construction industry. A qualitative approach was based on prime contractor's perspective at the construction phase of the project. The survey questionnaire was designed by synthesizing and inheriting the previous studies and consultation with experts. The survey participants are those who have had working experience with main contractors and joined in the construction projects. The face-to-face interviews were conducted to collect data. Descriptive statistics analysis and Exploratory Factor Analysis (EFA) were used to analyze data. The results indicated seven leading causes which limited the application of SCM in the construction industry.
\end{abstract}

Keywords: supply chain management (SCM), limiting factors, construction industry.

\section{INTRODUCTION}

Construction industry is one of the main economic sectors playing an important role in country's economic growth $[2,16]$. It faced many difficulties due to the impacts of the economic crisis. However, in recent years, the construction industry in Vietnam has shown signs of recovery. In 2014, the total value of construction sector reached 211.200 billion VND, increasing $6.2 \%$, compared to the year 2013. In addition, Vietnam has integrated into the international mar- ket when joining the World Trade Organization (WTO) $\left(11^{\text {th }}\right.$ January 2007), signing the Vietnam - Korea Free Trade Agreement (VKFTA) ( $5^{\text {th }}$ May 2015), the Vietnam - Eurasian Economic Union Free Trade Agreement (29 $9^{\text {th }}$ May 2015), and the Trans-Pacific Strategic Economic Partnership Agreement (TPP) (4 ${ }^{\text {th }}$ February 2016). These not only brought many opportunities but also created significant challenges for Vietnamese businesses when they have to compete in today's fiercely competitive environment. Construction firms in Vietnam have to compete with not only domestic 


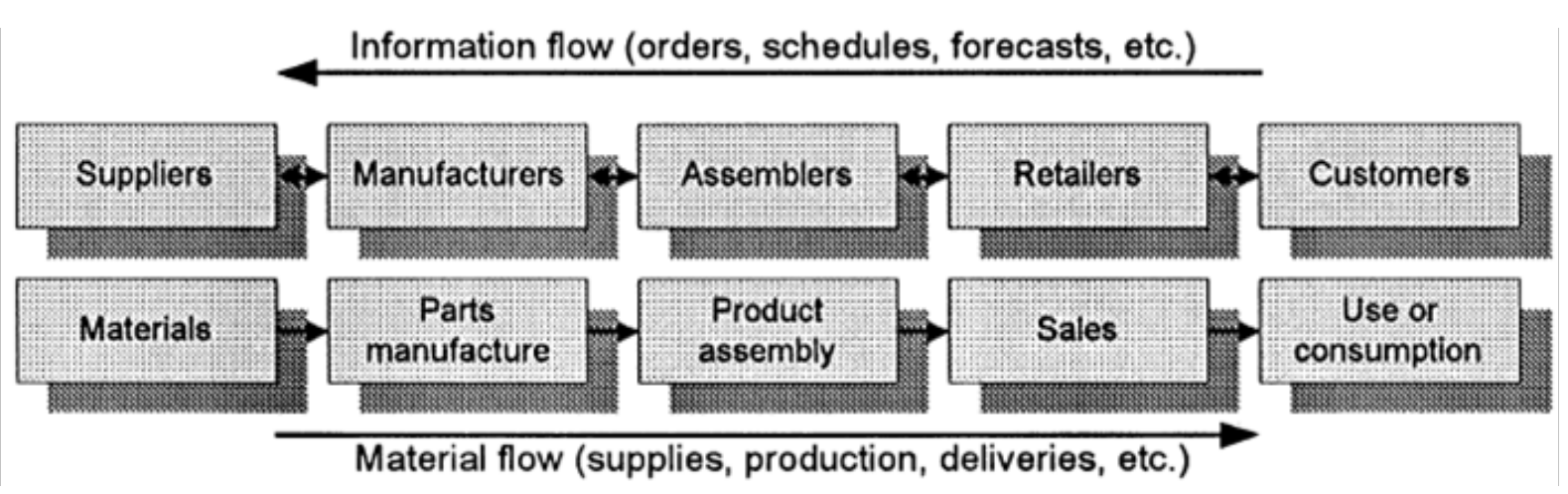

Fig. 1. Generic configuration of a supply chain in manufacturing [20]

companies but also foreign corporations. Thus, the current demand for innovations to improve the efficiency of the construction industry and increase the competitive advantage of its companies is very urgent.

SCM technique has been widely applied to various professions, especially in the manufacturing sector. Its efficiency helped many industries to lift productivity and competitive capacity at the current global market. The successful SCM applications of Wal-Mart, Procter and Gamble, Ford, and Dell are typical examples. As a result, they have become the leading firms in the markets. In Vietnam, Vinamilk company has also achieved great success from the application of SCM in their business activities. Therefore, SCM is considered as an appropriate method that can meet the urgent needs of the Vietnam's construction sector. Despite the present recognition of SCM importance, its application for the construction industry in general and Vietnam's, in particular, is limited. Therefore, it is essential to find the causes of such limitation.

\section{RESEARCH BACKGROUND}

This part begins with the supply chain management in manufacturing and construction industry. It then presents the characteristics of construction supply chain. Finally, the status of supply chain management application to construction industry is discussed.

\section{Supply Chain and Supply Chain Management in Manufacturing}

Some definitions have been proposed concerning the concept of the supply chain and its management $[3,4,5]$. In general, in the Figure 1, the supply chain in manufacturing can be stated as the activities network of companies being involved from raw material to finished product and delivery to the customers [11]. Therefore, SCM can be defined as the manipulations impact on the operations of the supply chain to gain the desired results, the coordination of manufacture, inventory, place and transport among the members of a supply chain with the aim to rhythmically and efficiently meet the market demands $[6,7,12]$.

\section{Supply Chain and Supply Chain Management in Construction}

Although the construction industry is much delayed than other sectors in applying SCM, many concepts are available, such as the ones suggested by $[18,22]$. However, in this research, the supply chain, and SCM are understood as follows: Supply chain is an activities network of involved companies (client/ owner, designer, consultant, the prime contractor, subcontractor, and supplier) to create and put a completed building to use. In Figure 2, each supply chain member is a link of one or many other chains, creating a complex network; SCM in construction is the ways that the firms used to raise the cooperation between stakeholders in the chain and link the key construction business processes [8]. Its purposes are to improve construction productivity, enhance competitive advantage and satisfy the client requirements at the lowest cost $[9,10]$.

\section{Characteristics of Construction Supply Chain}

The construction supply chain is characterized by the following elements $[13,14,15]$ :

- Convergent supply chain: Directing all materials to the construction site. The "construc- 


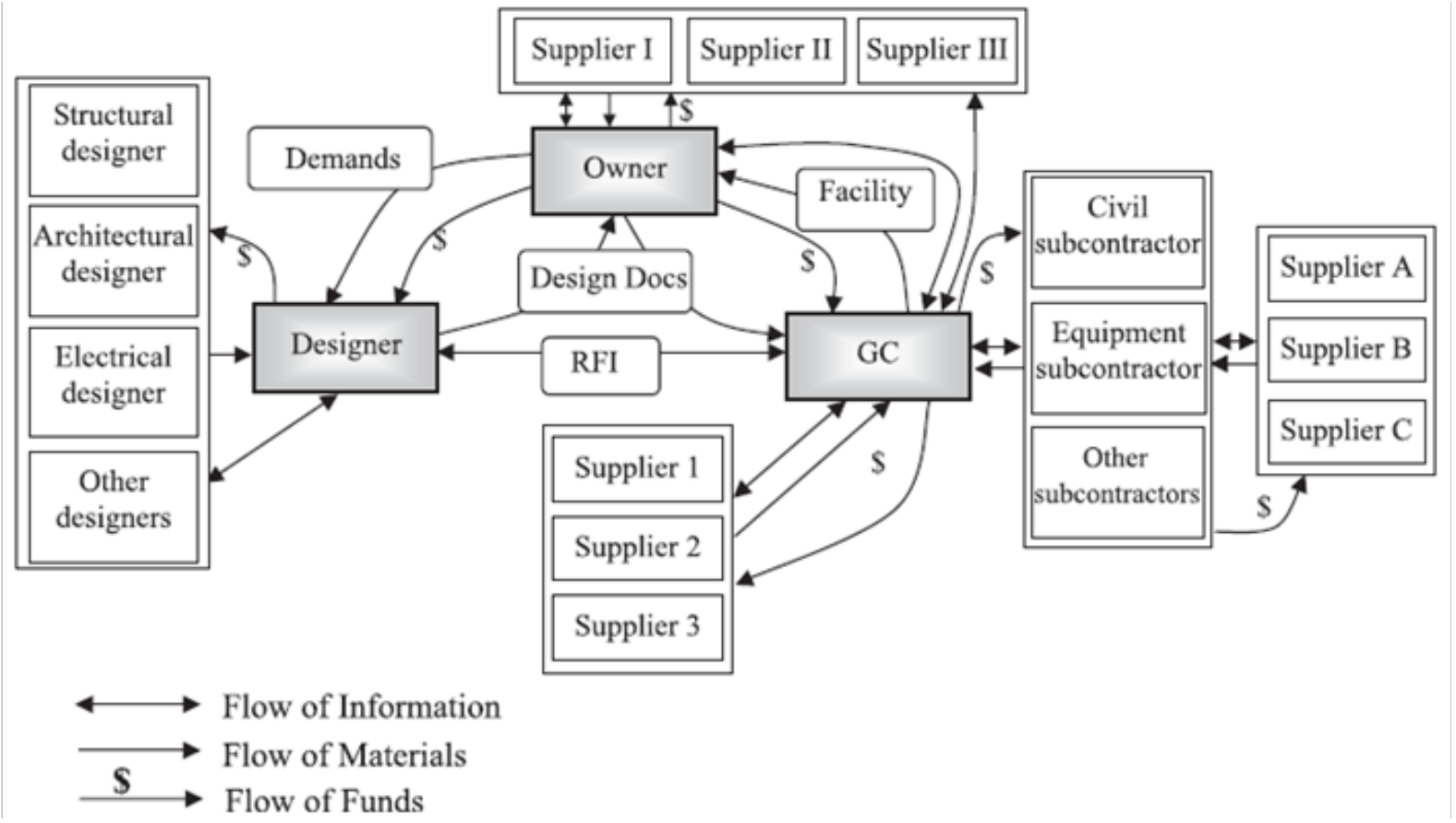

Fig. 2. Model of construction supply chain [22]

tion factory" is set up for a single product, in contrast to systems of manufacturing where multiple products pass through the plant and distribute to customers.

- Pull supply chain: Products are derived from the requirements of the owners, they find the main contractors who can meet their demands. The main contractors continue to find the subcontractors, suppliers that can help them to complete the project. This process continues to create a construction supply chain.

- Make-to-order supply chain: Each project creates a new product. There is little repetition except for some special cases.

- Apart from rare exceptions, a supply chain is only used for a single project, and the duration of the chain depends on the project life cycle. As a result, the construction supply chain is typified by temporality, instability and fragmentation.

\section{Status of Supply Chain Management Application to Construction Industry in Vietnam}

Vietnam has gradually integrated into the international market. Therefore, the local contractors need to find the development strategies to be able to compete against the foreign contractors. It is said that only a small number of domestic con- tractors have the opportunity to access the world advanced management and construction techniques. Also, domestic contractors are in the need of supporting industry to compete at the global level. Currently, only some of the big contractors such as CotecCons (CTD) and Hoa Binh (HBC) attempt to carry out the Design - Build model and BIM system to create the added values and improve their gross margin. It could be the upcoming trend and strategy for Vietnamese constructors.

Beside Design - Build model and BIM system, SCM technique also meets the current demands of Vietnam's construction industry. However, its concept is not popular. The survey result shows a significant number of respondents $(72 \%)$ agreed that applying SCM to construction is essential. Also, some of the core benefits were achieved when respondents had agreed on implementing SCM. First, it brings many advantages to all members of supply chain and contributes to improving efficiency. Second, it helps to resolve adversarial relationships among the project stakeholders; and create favorable conditions for all members of the supply chain to coordinate together.

However, it was found that some problems remained with the Vietnamese construction. For instance, $97.5 \%$ of respondents adopt the primary ways (mail, fax, telephone or face-to-face) to connect and share supply information. Only $2.5 \%$ of them use connected information systems 
and have a computer program that is specialized in supply. The major way employed by contractors from materials procurement depends on the site request $(88.6 \%)$. It is the simplest purchase method and the only aim to satisfy the location material demands without optimizing calculation. Moreover, the subcontractors work scheduling is often proposed by themselves (43\%), by the main contractor $(27.8 \%)$ and by the combination of the main contractor and their subcontractors (29.1\%). All of these challenge the contractors to implement SCM. Thus, the causes of restriction to SCM application are not only innovation aversion, but also other barrier factors, such as the sector characteristics, lack of SCM knowledge, inappropriate organization structure to support the system.

\section{RESEARCH METHODOLOGY}

At the onset, the preliminary list of 39 limiting factors in applying SCM to the construction sector are identified by synthesizing from other sources like textbooks, journals, and previous studies. However, most of the documents were originated in different countries, so the experts' consultation was carried out to match with the Vietnam context. A group including nine professionals who have extensive experience in project management and participated in large-scale projects valued over 200 billion VND, were invited to assess, select from the preliminary list of factors and add many factors that they experienced in practice. Among nine experts, there are one with over 20 experience-year, followed by three with over 16 years, two with over 11 years and three with over five years. After several face to face interviews with these experts, 30 factors were extracted from 39 original factors and put in the survey questionnaire in the table 1.

The participants for the survey are the people who have experiences in working with the main contractors and joined the civil and industrial projects. The face-to-face interview was conducted to collect data. The respondents were asked to indicate the limited level of the factors by using a five-point Likert scale from 1= "least extent" to $5=$ "great extent" [1].

Eighty-six valid responses with 3 from senior managers (3.5\%), 22 from project managers or (deputy) project directors $(25.6 \%), 16$ from construction site commanders (18.6\%), 34 from members of project management department (39.5\%), 11 from low-level managers or engineers $(12.8 \%)$ were obtained after the data collecting process. Regarding working experience, there are one people with over 20 years (1.2\%), nine people with $16-20$ years $(10.5 \%)$, nine people with $11-15$ years $(10.5 \%), 51$ people with 5-10 years (59.3\%), and 16 people with 3-5 years (18.6\%). For project scale, over 200 billion VND projects share $47.7 \%$ with 41 participants. The proportion of 100-200 billion VND projects, 50-100 billion VND projects and under 50 billion VND projects are $15.1 \%$ of 13 people, $14 \%$ of 12 people and $23.3 \%$ of 20 people respectively.

\section{DATA ANALYSIS}

In this research, data analysis was undertaken using the descriptive statistics analysis method combined with exploratory factor analysis by IBM SPSS Statistics Version 23. The A7 and B19 factors were removed when testing scale reliability through Cronbach's alpha coefficient. The results show six groups of main reasons caused the limitation to SCM application for the construction industry in Vietnam. They are labeled and presented in the Table 2, 3 and 4.

\section{DISCUSSION}

Based on the component of the construction characteristics, together with six components obtained from the exploratory factors analysis, it can be concluded that the application of SCM to Vietnamese construction industry is limited by seven major causes including (1) the characteristics of construction industry; (2) the company's SCM capability approaches; (3) lack of awareness of the importance of coordination and support among the project stakeholders; (4) the inappropriate supply chain creation support systems; (5) the poor maintaining of collaborative relationships; (6) lack of experience of innovations; and (7) lack of appropriate information technology systems.

\section{The characteristics of the construction industry}

They are barriers to applying SCM. The temporary and short-term of construction projects lead to the difficult creation of long-term relationship and the mutual support among the members involving projects. Also, the participation of many organizations at the same time, as well as uncertainty and frequent changes during the project implementation process, made the construc- 
Table 1. Thirty factors were extracted from 39 original factors

\begin{tabular}{|c|c|}
\hline & The limiting factors \\
\hline A & Group of factors related to the sector characteristic \\
\hline 1 & The temporary and short-term of construction project \\
\hline 2 & The complexity of construction project (there are many components involved in the supply chain) \\
\hline 3 & $\begin{array}{c}\text { The uncertainty and frequent changes of construction project (The changes usually from commands of owner lead to the } \\
\text { change of project implementation plan) }\end{array}$ \\
\hline 4 & The uniqueness of construction project (each project construction is different in size, resources, and implementation method) \\
\hline 5 & There are more conflicts and disputes than other industries \\
\hline 6 & No standardization in the construction project of labor, machinery, equipment, and so forth. \\
\hline 7 & $\begin{array}{l}\text { Strong affection by many external factors: human, social, weather and other natural elements that lead to high risk (legal } \\
\text { aspect, price fluctuations, labor safety, and so forth) }\end{array}$ \\
\hline B & Group of factors related to the participants in a project (Owner, Designer, Contractor, Consultant, Supplier): \\
\hline 1 & Lack of understanding of supply chain and supply chain management \\
\hline 2 & Lack of top management commitment \\
\hline 3 & Inappropriate organization structure to support system \\
\hline 4 & Fragmented processes \\
\hline 5 & Lack of appropriate information technology system \\
\hline 6 & Insufficient resources to integrate processes and manage logistics within a one-off project environment \\
\hline 7 & Lack of experience in innovations ( $\mathrm{JIT}, \mathrm{BIM}, \mathrm{TQM}, \ldots$ ) \\
\hline 8 & The emphasis on individual interests rather than the common interests of the project members \\
\hline 9 & The weakness in the internal management of the units involved \\
\hline 10 & Deficiency trusts in the partner competence \\
\hline 11 & Lack of coordination and mutuality among the partners joined the process \\
\hline 12 & Adversarial relationships among the participants in the project \\
\hline 13 & Less transparency, limitation and inadequacy in sharing the project information and communication \\
\hline 14 & Applicability is limited by the competitive bidding process (Prime focus on bid prices, without focus on real cost) \\
\hline 15 & Lack of initial preparation of organizations involved in the project's supply chain \\
\hline 16 & Lack of awareness of the benefits and importance of adopting supply chain management in construction projects \\
\hline 17 & Low commitment of partners \\
\hline 18 & $\begin{array}{l}\text { The professional contractors were not involved early in processes of the projects (because the owners selected inap- } \\
\text { propriate contractor at the beginning of stage) }\end{array}$ \\
\hline 19 & The residual power between the participants \\
\hline 20 & Minimal or no direct interactions that foster long-term sustainable relationships with the partners \\
\hline 21 & $\begin{array}{c}\text { Lack of possible partners with the appropriate collaborative capability (regarding scale, available resources to meet the } \\
\text { requirements when joining the chain) }\end{array}$ \\
\hline 22 & Differences in language, procedure and process when it has the participation of foreign firms \\
\hline 23 & The owner financing does not satisfy the chain's requirements \\
\hline
\end{tabular}

Table 2. Ranking the sector characteristics' factors according to the average value

\begin{tabular}{|c|c|c|}
\hline & Factors & Mean \\
\hline A3 & $\begin{array}{c}\text { The uncertainty and frequent changes of construction projects (The changes usually from commands of } \\
\text { owner lead to the change of project implementation plan) }\end{array}$ & 3.53 \\
\hline A6 & No standardization in construction projects of labor, machinery, equipment. & 3.44 \\
\hline A2 & The complexity of construction projects (there are many components involved in the supply chain) & 3.37 \\
\hline A5 & There are more conflicts and disputes than other industries & 3.28 \\
\hline A1 & The temporary and short-term of construction projects & 3.12 \\
\hline A4 & $\begin{array}{c}\text { The uniqueness of construction projects (each project construction is different in size, resources, and imple- } \\
\text { mentation method) }\end{array}$ & 2.98 \\
\hline
\end{tabular}


Table 3. Ranking factors related to the participants in a project according to the average value

\begin{tabular}{|c|c|c|}
\hline & Factors & Mean \\
\hline B1 & Lack of understanding of supply chain and supply chain management & 3.81 \\
\hline B8 & The emphasis on individual interests rather than the common interests of the project members & 3.71 \\
\hline B23 & The owner financing does not satisfy the chain's requirements & 3.65 \\
\hline B16 & $\begin{array}{l}\text { Lack of awareness of the benefits and importance of adopting supply chain management in construction } \\
\text { projects }\end{array}$ & 3.63 \\
\hline B9 & The weakness in the internal management of the units involved & 3.62 \\
\hline B2 & Lack of top management commitment & 3.60 \\
\hline B14 & Applicability is limited by the competitive bidding process (Prime focus on bid prices, without focus on real cost) & 3.53 \\
\hline B13 & Less transparency, limitation and inadequacy in sharing the project information and communication & 3.51 \\
\hline B11 & Lack of coordination and mutuality among the partners joined in the process & 3.49 \\
\hline B7 & Lack of experience in innovations (JIT, BIM, TQM, and so forth) & 3.49 \\
\hline B3 & Inappropriate organization structure to support system & 3.49 \\
\hline B12 & Adversarial relationships among the participants in the project & 3.45 \\
\hline B15 & Lack of initial preparation of organizations involved in the project's supply chain & 3.44 \\
\hline B21 & $\begin{array}{l}\text { Lack of possible partners with the appropriate collaborative capability (regarding scale, available resources } \\
\text { to meet the requirements when joining the chain) }\end{array}$ & 3.42 \\
\hline B6 & Insufficient resources to integrate processes and manage logistics within a one-off project environment & 3.42 \\
\hline B4 & Fragmented processes & 3.35 \\
\hline B10 & Deficiency trusts in the partner competence & 3.33 \\
\hline B5 & Lack of appropriate information technology system & 3.28 \\
\hline B22 & Differences in language, procedure and process when it has the participation of foreign firms & 3.14 \\
\hline B20 & Minimal or no direct interactions that foster long-term sustainable relationships with the partners & 3.14 \\
\hline B18 & $\begin{array}{l}\text { The professional contractors were not involved early in processes of the projects (because the owners } \\
\text { selected inappropriate contractor at the beginning stage) }\end{array}$ & 2.94 \\
\hline B17 & Low commitment of partners & 2.94 \\
\hline
\end{tabular}

tion have more conflicts and disputes than other industries, creating obstacles for managing a supply chain. Additionally, each project has its characteristics and no standardization in construction projects of labor, machinery, equipment, as a result, many aspects have to be considered to select appropriate supply chain with the demands on the resources (finance, labor, and machinery) to meet requirements of chains. This multiple is also an issue of the construction sector.

\section{The company's SCM capability approaches to apply SCM}

The understanding and equipment of every member of a supply chain about mind, knowledge, support structure, available resources are crucial; these will be facilitated when they take part in the chain. Also, each participant who comes from various independent organizations will always focus on individual interests, rather than common interests, therefore, conflicts are created. The deficiency trust in the partner competence has also been mentioned. These factors make the coordination and mutuality harder to apply, especially when the problem is happening, each member will handle it themself without, mutual discussion to find the best solution. It makes the SCM ineffective and wasteful.

\section{Lack of awareness of the importance of coordination and support among the project stakeholders}

The coordination and support among the project stakeholders play important roles in SCM. They help complete tasks efficiently and effectively. However, due to lack of awareness of their importance, many problems still exist in chains. First, it is adversarial relationships among the participants in the project, and less transparency. Second, it has limitation, and inadequacy in sharing the project information and communication; and lack of initial preparation of organizations involved in the project's supply chain. Third, the professional contractors did not participate early in processes of the projects; lack of coordination and mutuality among the partners joined the process. There- 
Table 4. Summary of Factor Analysis results

\begin{tabular}{|c|c|c|c|}
\hline Components & $\begin{array}{l}\text { Factor } \\
\text { Loading }\end{array}$ & $\begin{array}{l}\text { Eigen- } \\
\text { values }\end{array}$ & $\begin{array}{c}\% \text { of } \\
\text { variance }\end{array}$ \\
\hline 1. The company's SCM capability approaches & & 3.552 & 16.148 \\
\hline Lack of understanding of supply chain and supply chain management & 0.665 & & \\
\hline Lack of top management commitment & 0.743 & & \\
\hline $\begin{array}{l}\text { Insufficient resources to integrate processes and manage logistics within a one-off } \\
\text { project environment }\end{array}$ & 0.586 & & \\
\hline $\begin{array}{l}\text { The emphasis on individual interests rather than the common interests of the } \\
\text { project members }\end{array}$ & 0.591 & & \\
\hline The weakness in the internal management of the units involved & 0.686 & & \\
\hline Deficiency trusts in the partner competence & 0.673 & & \\
\hline $\begin{array}{l}\text { 2. The awareness of the importance of coordination and support among the } \\
\text { project stakeholders }\end{array}$ & & 2.946 & 13.389 \\
\hline Lack of coordination and mutuality among the partners joined the process & 0.630 & & \\
\hline Adversarial relationships among the participants in the project & 0.612 & & \\
\hline $\begin{array}{l}\text { Less transparency, limitation and inadequacy in sharing the project information } \\
\text { and communication }\end{array}$ & 0.636 & & \\
\hline Lack of initial preparation of organizations involved in the project's supply chain & 0.620 & & \\
\hline $\begin{array}{l}\text { Lack of awareness of the benefits and importance of the adopting supply chain } \\
\text { management in construction projects }\end{array}$ & 0.579 & & \\
\hline $\begin{array}{l}\text { The professional contractors were not involved early in processes of the projects } \\
\text { (because the owners selected inappropriate contractor at the beginning stage) }\end{array}$ & 0.685 & & \\
\hline 3. The inappropriate supply chain creation support systems & & 2.367 & 10.760 \\
\hline Inappropriate organization structure to support system & 0.557 & & \\
\hline Fragmented processes & 0.706 & & \\
\hline Low commitment of partners & 0.685 & & \\
\hline $\begin{array}{l}\begin{array}{c}\text { Differences in language, procedure and process when it has the participation of } \\
\text { foreign firms }\end{array} \\
\end{array}$ & 0.560 & & \\
\hline The owner financing does not satisfy the chain's requirements & 0.573 & & \\
\hline 4. The poor maintaining of collaborative relationships & & 2.002 & 9.101 \\
\hline $\begin{array}{l}\text { Applicability is limited by the competitive bidding process (Prime focus on bid } \\
\text { prices, without focus on real cost) }\end{array}$ & 0.749 & & \\
\hline $\begin{array}{l}\text { Minimal or no direct interactions that foster long-term sustainable relationships } \\
\text { with the partners }\end{array}$ & 0.615 & & \\
\hline $\begin{array}{l}\text { Lack of possible partners with the appropriate collaborative capability (regarding } \\
\text { scale, available resources to meet the requirements when joining the chain) }\end{array}$ & 0.615 & & \\
\hline 5. The experience of innovations & & 1.736 & 7.890 \\
\hline Lack of experience in innovations ( JIT, BIM, TQM...) & 0.839 & & \\
\hline 6. The appropriate information technology systems & & 1.333 & 6.060 \\
\hline Lack of appropriate information technology system & 0.840 & & \\
\hline
\end{tabular}

fore, the organizations that want to apply the SCM should perceive and solve these problems.

\section{The inappropriate supply chain creation support systems}

This group often results in the fracture or disruption within supply chains, in which, the owner financing greatly influences the SCM decision making. Besides, enterprises have not yet mastered the SCM. As a consequence, the organizational structure and operating mechanisms are not effective. The activities of the supply chain are separated, and the businesses do not have mechanisms to link them. Furthermore, the commitment of partners has a significant role. The clear division of interest, obligation, and responsibility of participants as well as among stakeholders helps to raise the effect of SCM.

\section{Poor maintaining of collaborative relationships}

The long-term collaborative relationships have benefits when implementing SCM. The col- 
laborative relationships in chains have been unstable and short-term by the factors in this group. In most countries, bidding is used to choose suitable contractors who are eligible to meet the project demands. However, choosing bidder with the focus on bid prices leads to many problems. First, it is an attempt to improve profit levels on the project through reductions in quality of materials; the contractor will attach particular importance to costs instead of project quality, and they do not have the ability and will to cooperate in giving innovations or collaborating to solve problems. Also, since the short life cycle of projects and myopic thinking of the project stakeholders, the long-term relationships are also not considered. The capability plays an important role when they want to achieve long-term relationships. Another problem is to find suitable partners. Therefore, maintaining a long-term collaborative relationship is a challenge in applying SCM.

\section{Lack of experience of innovations}

Ruben Vrijhoef and Lauri Koskela (2010) found that the wastes and problems of chains are widely caused by obsolete and myopic in the chain driver. So, applying SCM and offering innovation are very essential. However, the shortage experience will bring bad results and make more waste. For example, the Buchhaugen project used JIT style delivery system and employed a unit order system where the project was split into small packages of material delivered to the site where they are needed, just as they are required. As a result, at least one firm (an intermediary materials handler or supply depot) found an overall increase in costs with the unit order system [1]. Therefore, we should consider this problem before applying SCM or any new methods.

\section{Lack of appropriate information technology systems}

In a construction project, from beginning to end, many participants and heavy set of documents, drawings are attached. Furthermore, there are many problems needed to coordinate and exchange rapidly to make decisions quickly when the project is implemented. Thus, in SCM, information technology (IT) is vital to meet the document management demands, as well as exchange information and coordinate partners rapidly and more efficiently, support to quickly and timely make decisions. However, Vietnam's construc- tion industry still has not had a suitable IT system. Most of the companies have manually managed their documents, exchanged information through direct conferences, phones, faxes or emails. This led to many mistakes and dangerous consequences. It can cause cost overrun, schedule delay, and difficulties when applying SCM. It is a barrier to the application of SCM in Vietnam.

\section{CONCLUSION}

The SCM helped many industries improve their performance and competitive capacity in today's global markets, especially in the manufacturing sector. However, the construction industry is limited to apply SCM technique. In this research, seven main causes of limitation to apply SCM application to Vietnamese construction industry are identified following the perspective of the main contractors at the construction phase of the project. Based on these results, the contractors can propose some solutions to help them reform and upgrade SCM application level. It will help contractors increase productivity, optimize costs and enhance their competitive advantage in the current fiercely competitive market. However, the concept of supply chain and SCM are relatively new to the construction industry in Vietnam. The collected data are still approximate despite trying to gather data by face-to-face interview because the respondents did not deeply understand the survey issue. Besides, this research only assesses the subject based on the viewpoint of the main contractors at construction phase of projects.

\section{ACKNOWLEDGEMENT}

The authors gratefully acknowledge Hochiminh City Open University (HCMCOU), Ho Chi Minh City University of Technology (HCMUT) and Chulalongkorn University (CU) for supporting this research.

\section{REFERENCES}

1. Aleksander L., Małgorzata L., and Rafał L. Different multidimensional exploratory techniques in classifying variables into qualitative criteria of spare parts selection for passenger cars. Advances in Science and Technology Research Journal, 10(31), 2016, 185-193.

2. Apollo, M., and Miszewska-Urbańska, E. Analysis of the increase of construction costs in urban regeneration projects. Advances in Science and Technology Research Journal, 9(28), 2015, 68-74. 
3. Akintoye, A., McIntosh, G., and Fitzgerald, E. A survey of supply chain collaboration and management in the UK construction industry. European Journal of Purchasing and Supply Management, 6(3), 2000, 159-168.

4. Albaloushi, H., and Skitmore, M. Supply chain management in the UAE construction industry. International Journal of Construction Management, 8(1), 2008, 53-71.

5. Azambuja, M., and O'Brien, W. Construction supply chain modeling: Issues and perspectives. Construction Supply Chain Management Handbook, 2009.

6. Behera, P., Mohanty, R., and Prakash, A. Understanding construction supply chain management. Production Planning and Control, 26(16), 2015, 1332-1350.

7. Benton, W., and McHenry, L. F. Construction purchasing and supply chain management: McGrawHill New York, 2010.

8. Dawood, N., Akinsola, A., and Hobbs, B. Development of automated communication of system for managing site information using internet technology. Automation in Construction, 11(5), 2002, 557-572.

9. de Souza, D. V. S., and Koskela, L. On improvement in construction supply chain management. Proc of 20th Annual Conference of the International Group for Lean Construction, 2012.

10. Deshmukh, P., More, A., and Chavan, S. Supply chain management in residential construction sector, 2007.

11. Houlihan, J. B. International supply chain management. International Journal of Physical Distribution and Materials Management, 15(1), 1985, 22-38.

12. Hugos, M. H. Essentials of supply chain management, John Wiley and Sons, 2011.

13. King, A. P., and Pitt, M. C. Supply chain management: A main contractor's perspective. Construc- tion Supply Chain Management: Concepts and Case Studies, 2009, 182-198.

14. Li, Z., Cheng, S., and Meng, Q. A modelling framework for construction supply chain simulation based on multi-agent. ICLEM, 2010, 4691-4698.

15. Morledge, R., Knight, A., Grada, M., and Pryke, $\mathrm{S}$. The concept and development of supply chain management in the uk construction industry. Construction Supply Chain Management, 2009, 23.

16. Nguyen T.P, Phuc N.V, and Quyen N. Application of Fuzzy Analytic Network Process and TOPSIS Method for Material Supplier Selection, Key Engineering Materials, 728, 2017, 411-415.

17. O'brien, W. J. Construction supply-chain management: A vision for advanced coordination, costing, and control. The NSF Berkeley-Stanford Construction Research Workshop, Stanford, California, 1999.

18. Serpell, A., and Heredia, B. Supply chain management in construction: Diagnosis and application issues. Globalisation and Construction, 2004, 455.

19. Song, S., and Fan, M. Research on a construction project supply chain. The ICCTP 2010 Integrated Transportation Systems: Green, Intelligent, Reliable, 2010.

20. Vrijhoef, R., and Koskela, L. The four roles of supply chain management in construction. European Journal of Purchasing and Supply Management, 6(3), 2010, 169-178.

21. Wang, S., Fang, J., Jiang, W., and Xie, Y. Delays in construction project supply chain. The Proceedings of International Conference on Information Management and Engineering (ICIME), 2011.

22. Xue, X., Li, X., Shen, Q., and Wang, Y. An agentbased framework for supply chain coordination in construction. Automation in Construction, 14(3), 2005, 413-430. 